Article

\title{
Built Form and Community Building in Residential Neighbourhoods: A Case Study of Physical Distance in Subiaco, Western Australia
}

\author{
Abu Yousuf Swapan ${ }^{1, *(1)}$, Joo Hwa Bay ${ }^{2}$ and Dora Marinova ${ }^{1}$ \\ 1 Curtin University Sustainability Policy Institute, Curtin University, Building 209, Bentley, Perth, WA 6102, \\ Australia; d.marinova@curtin.edu.au \\ 2 School of Design \& the Built Environment, Curtin University, Bentley, Perth, WA 6102, Australia; \\ philipjhbay@yahoo.com \\ * Correspondence: swapan4794@gmail.com; Tel.: +61-469-870-695
}

Received: 20 April 2018; Accepted: 21 May 2018; Published: 23 May 2018

\begin{abstract}
With physical and social aspects being inseparable within urban environments, design for sustainability needs to include the link between the distance and sense of community. However, only a few studies examine residential suburbs and specifically focus on the physical and social interactions occurring within the streets and adjacent to them spaces, such as verges, sidewalks and front yards. Using a case study method, including observation and a perception-based survey in the inner-city suburb of Subiaco in Perth, Western Australia, this investigation opens up a new understanding of physical distance and social interaction. It develops a novel typology of physical distances and social closeness within a residential neighbourhood which allows better conceptualising the sense of community for achieving integrated sustainability.
\end{abstract}

Keywords: social sustainability; sense of community; quality of life; community building; built form typology; front yard; street; communication; social interaction; distance; closeness; social bonding

\section{Introduction}

The integration of all aspects of sustainability is attracting increasing attention, particularly in relation to urban environments [1,2] where the majority of the world population now lives $(54 \%$ in 2014 , expected to reach $66 \%$ by 2050 [3]). A major priority for 21 st century living is urban areas to provide a good quality of life in terms of housing and health $[4,5]$ but also regarding the more intangible properties which describe social cohesion and sense of community. The United Nations' Sustainable Development Goal 11 Sustainable Cities and Communities specifically emphasises safety and inclusivity of access to green and public spaces as places which integrate environmental, social and economic opportunities. Whilst there is a broad understanding of the importance of public open spaces, residential neighbourhoods also deserve attention.

Residential streets $[6,7]$ are a typical example of public spaces that can contribute to the sense of community. Adjacent and connected to residential streets are house fronts which, although legally private, represent very unique semi-private-public spaces with the potential to enhance urban quality of life [8]. If properly designed, they not only make residential streets more attractive but also offer opportunities for socialising and social interactions. This study focussed on understanding the links between physical distance and social interactions within the context of residential streets with adjacent front yards using a case study from Perth, Western Australia. It aimed to develop a typology through examining linear distances (physical and perceived) and social interactions related to one particular built form, namely the front yard. Such neighbourhood-based studies are rare despite the obvious link between the physical and social factors and their influence on human behaviour. Understanding the 
social dimension through the physical distance opens new opportunities to create more sustainable and resilient communities.

This paper first discusses the theoretical framework which connects the concepts of sense of community with the built form and human behaviour at a neighbourhood scale. The adopted methodology for the case study is then explained and the research findings are presented. A new typology of the link between physical distance and social interaction, referred to as typology of social closeness, is developed. This allows for better appreciation of the connection between urban built form and sense of community within residential neighbourhood settings.

\subsection{Sense of Community and the Built Form}

The built environment-the expression used to represent urban areas-is often juxtaposed to the natural habitat characteristic of rural settlements [9]. Its functions are not only to provide shelter for human activities but also "to define patterns of movements" as well as "patterns of encounter and co-presence" [10] (p. 26). Urban design, planning and architecture are projected to last for decades, if not centuries [11], potentially making cities a catalyst for sustainable development [12]. Sustainability as a conceptual urban framework also incorporates the development of sense of place and sense of community [13] which contribute to improved quality of life, social relationships and interactions between the physical form and city dwellers as well as among neighbourhood residents and visitors. Social cohesion within the built environment becomes a counteracting factor to urban decay and makes residential neighbourhoods desirable and attractive.

By definition, the sense of community is a "feeling" [14] of belonging and of individuals being important to each other; a shared faith that community members' needs will be valued with commitment [15]. These relational feelings contribute to the quality of life defined by the relations between individuals and their physical and social environment [16]. Within a neighbourhood, residents develop both strong and weak relationships [17]. Physical distance can impact on the strength and nature of these relationship. The intensity of the relationships can also vary from, for example, saying hello to working as a group [18]. Both chance encounters between neighbours and more intimate social relationships within a neighbourhood reinforce the sense of community [18] (p. 192).

Urban design and typology shape the environment within which the feelings of community belonging and attachment develop. In fact, new urbanism calls for built form and urban space typologies which create modern cities of human scale and sense of community [19]. Scholars [20-24] strongly advocate for place-based social sustainability to foster interactive vibrant communities [5,25-27]. Sustainability thus becomes the outcome from the combined effort of creating the physical and social environment [28]. Urban design is used as a tool shaping human behaviour $[29,30]$ and encouraging certain conduct and activities, such as in community celebrations, whilst discouraging others, such as for crime prevention [31]. Understanding the impact physical distance has on social interactions is one unexplored area of the built form design's role for sustainability.

\subsection{Built form Typology}

The typology of the built form sheds light on how urban spaces function and the interface they provide between the public and private realms [19]. Being the study of types, in the field of urban planning and architecture typology refers to the taxonomic classifications of places and buildings in reference to various criteria, such as location (rural or urban), use (agricultural, commercial, residential, medical, educational, governmental, industrial, etc.), age (old or new), etc. An assembly of indoor and outdoor space types helps form the physical language of architecture by organising public-private zoning to achieve a desired architectural experience [32] (p. 14). Normally, building types are identified by their basic form, surroundings or scale but not by their architectural style [33]. The role of types in modern architecture allows to incorporate upcoming developments without mimicking historic expressions and styles emerged in the course of time [34] as well as maintain continuity in the 
cityscape [33]. New urbanists recognise typology as a vital means to further define user-friendly places $[33,35]$.

Moudon $[34,36]$ identified blocks, lots and street patterns as essential for typological consistency in neighbourhood design. Normally, neighbourhood streets and lots are readymade infrastructures or the "building blocks" for the city. In the pre-design phase, the common urban tissue patterns-a combination of streets, lots and public open spaces-are identified to inter-relate and form the neighbourhood. This urban fabric provides the physical environment and surroundings for the sense of community to emerge and make neighbourhood areas socially active.

As there are no distinctive tools for measuring social sustainability in neighbourhood design, one possible way to analyse the sense of community is through creating a typology of the places perceived by people as contributing towards this. Within the well-defined boundaries which spatially position a neighbourhood, social interactions are the ones creating a sense of community as they allow for emotional connections and social relationships to build up. Hence, the front yard is an important space for social interactions.

\subsection{Private-Public Interface}

Within a residential neighbourhood, the front yard, which we describe as a "semi-private-public" place [8], is the interface between the public realm, represented by the streets and the private domain, represented by the blocks with houses. It is the extension of other forms of interface, such as public sidewalks, pedestrian paths, walkways, and access lanes, which balance power relations and where privacy acts as a stabiliser between private and public [37]. According to Simmel [38], this interface is a separating and connecting device, where strangers are greeted or excluded [39] and where exposure and confidentiality are frequent.

The front yard in all of its manifestations, such as front garden, veranda, porch, entrance deck, plinth, al fresco dining place, etc., represents a socialising and activity interstitial space which welcomes visitors as well as establishes boundary, transparency, identity and natural surveillance ensuring the feeling of safety [40]. This built form is something in between indoor and outdoor, leading from inward to outward to pedestrian areas and ending in the streets (or vice versa). Gehl [41] emphasised its importance in providing opportunities for prolonged outdoor stays and therefore increased social interaction among community members. Social interaction can also be intensified by adding stationary (ledges, stoops, steps, and low walls) or mobile (chairs, stools, and benches) sitting arrangements [42].

However, the line between the real and symbolic ownership [43] of the interface places can be blurred. For example, private space, if visible, can perform as public [43-45] even without physical accessibility. Furthermore, the residents' sense of control over the privately owned front yard can extend towards the adjacent public space types, such as sidewalks, verges and streets. These activities interconnect neighbours not only through face-to-face encounters, but also through spiritual relationships [14] where the physical space works as a common ground for social interaction.

\subsection{Physical Distance}

The main defining characteristic of a neighbourhood is physical proximity. Residential neighbourhoods act as common places and "behaviour settings" [46] where community building tends to develop by way of familiarisation through seeing, meeting and greeting [47]. Residents' daily life routines offer opportunities to create physical familiarity as well as social acquaintances and friendships [47]. Close juxtaposition also makes people interact more frequently [48] and this kind of regular mixing is adaptive rather than optional. The "mere exposure effect" [49] claims that repeated acquaintance creates positive familiarity between individuals.

In fact, in a neighbourhood the physical distance between individuals either brings them closer towards stronger intimate relationships, or helps them maintain a weak relationship of minimum interaction which is also needful to survive in a community (see Figure 1). Social space can be characterised objectively, namely through physical distance, or subjectively, for example through the 
perception of distance. Observation is the method used to capture physical distance while perception surveys collect people's opinions which also predict future behaviour [50]. Applying observation and perception can provide insights as to how people relate to each other, their neighbours and the built form. This in turn can inform the potential for community building and quality of life in a residential neighbourhood.

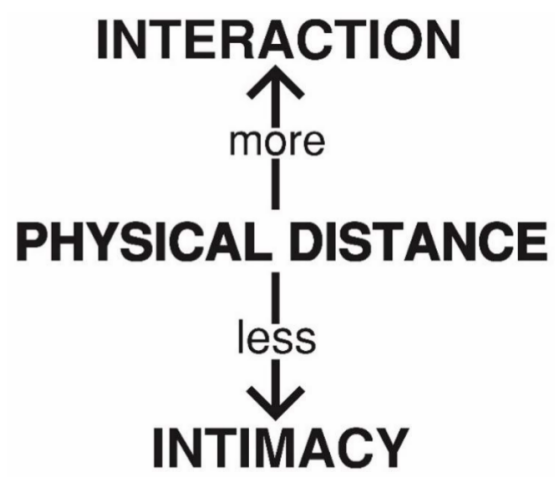

Figure 1. Relationship between distance, interaction and intimacy (Source: Authors).

Table 1 summarises the theoretical frameworks which link social interactions with physical distance together with the methods used for theory testing. According to Hall [51], physical closeness can be applied to measure the level of socialisation, including interpersonal communications and the use of senses (smell, hearing, sight, touch and taste in relation to food). He also explained that human perception works better horizontally for establishing personal space and relationships (rather than vertically where a sense of hierarchy or sub-ordinance may be implied) [51]. Gehl [52] stressed the importance of passive participation, chance encounter and acquaintance as low-intensity contacts in the private-public interface which provide important opportunities for participation in public life. However, physical distance as a social indicator has been widely ignored [53], particularly in relation to socialising in a residential context [54]. Latané's [55] theory of social impact is a rare exception according to which "immediacy" (intimacy/closeness) is inversely affected by physical distance and social interactions-intimacy, time spent, recalling memories, attentiveness and persuasiveness-decrease as distance increases [56,57]. Studies of social behaviour related to physical space are also scarce, with Bay's [58-60] enquiry into the convenient size of semi-open spaces (such as forecourt) in multi-storeyed living being such an example.

Table 1. Theoretical frameworks linking social interactions with physical distance.

\begin{tabular}{lll}
\hline Theorist & Theory & Method Used \\
\hline Hall [51] & $\begin{array}{l}\text { Human perception works better horizontally and } \\
\text { physical distance influences social relationships. }\end{array}$ & Literature review \\
\hline Gehl [52] & $\begin{array}{l}\text { Various social dimensions (based on linear physical } \\
\text { distance) affect human perceptions during } \\
\text { socialisation in public places. }\end{array}$ & $\begin{array}{l}\text { Observation } \\
\text { Perception survey }\end{array}$ \\
\hline Latané et al. [54,56] & $\begin{array}{l}\text { Social interaction is extensively determined by the } \\
\text { physical distance between two individuals; } \\
\text { immediacy is inversely proportional to } \\
\text { physical distance. }\end{array}$ & Literature review \\
\hline Wang and Bay [60] & $\begin{array}{l}\text { Optimum size for semi-open } \\
\text { forecourt/veranda/front-yard can ensure maximum } \\
\text { positive socialising output in high-rise residential } \\
\text { buildings of Singapore. }\end{array}$ & $\begin{array}{l}\text { Observation } \\
\text { Perception survey }\end{array}$ \\
\hline
\end{tabular}


Technological advantages, such as the telephone, Internet, computer, automobile and high-speed mass transit, have made communication easier than ever before. Nevertheless, face-to-face or chance encounters are still more appealing to people than emails or other electronic media [61]. Many argue that physical space is superior to virtual presence [62-64]. Therefore, this research explores the potential of physical distance to influence social relations and applies it as an indicator for interactions and community building using one particular case study—a neighbourhood in the Subiaco suburb of Perth, Western Australia. The study creates and explores a typology of places for social interactions based on physical distance.

\section{Methodology and Case Study}

The definition of the sense of community and its links to the built form provide the framework for studying residential front yards from a physical distance perspective. These semi private-public spaces are seen as essential in residential neighbourhoods for community building and good quality of life.

\subsection{Methods}

The aim of the study, approved by Curtin University Human Research Ethics Committee, was to analyse the contribution of the front yard to creating a sense of community by analysing the observed and perceived physical distance. A mixed-method approach $[65,66]$ was applied which combined:

1. Neighbourhood selection and case study description [67];

2. Detailed observation $[42,52,68,69]$, particularly of streets and front yards; and

3. Perception-based survey [70].

Using the mixed-method approach allows for cross-evaluation of observation and perception analysis within a neighbourhood case study [65-67]. This is utilised, among others, in architecture [42], urban design [52,69] and behavioural studies [66]. A case study is a well-defined unit of analysis which requires a detailed, in-depth depiction to generate new knowledge in complex social investigations which is very different from a numerical or statistical description of multiple items, places, events or phenomena. The choice of the case study is based on the researchers' interests and its ability to provide a basis for analytical development and conceptual generalisation [67]. After the residential neighbourhood in Subiaco was selected for the purpose of creating a new front-yard typology, the actual research steps taken followed those presented in Figure 2.

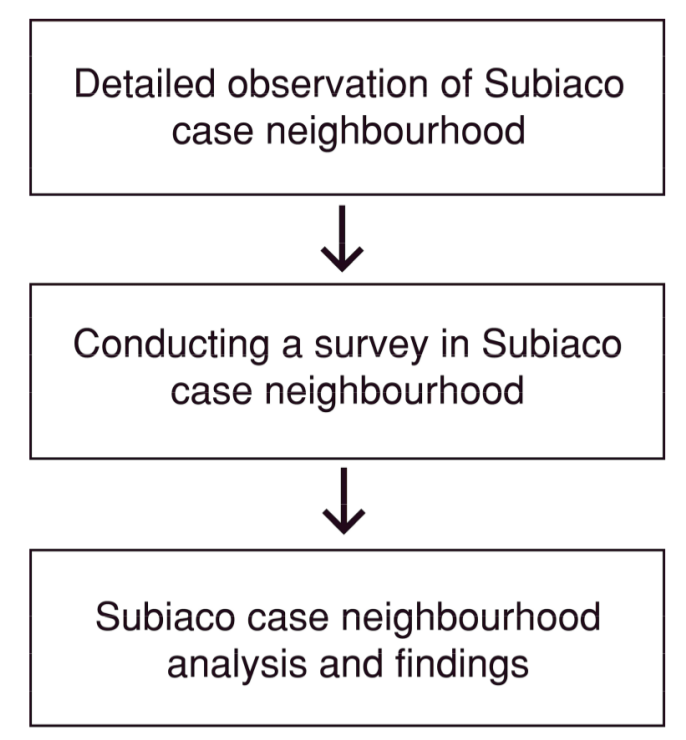

Figure 2. Research steps (Source: Authors). 
Observation was conducted on all streets and front yards of the selected case neighbourhood. Activities in all front yards were observed on a street by street basis during the spring and summer seasons of 2016 and 2017 in different daytimes of weekdays and weekends. The physical distances between the edges of the verandas and the centre points of the sidewalks were measured for all houses with AutoCAD software. This allowed for the front yard - the most significant residential outdoor space- to be analysed from the point of view of physical distance which was then linked to the level of social closeness. For example, physical distance of $20 \mathrm{~m}$ was identified as recognisable as people's gestures and postures are identifiable.

The perception survey was conducted with 61 residents in the case neighbourhood using semi-structured interviews. Based on the processed, organised and interpreted information acquired through the human senses [71] (p. 1604), perception influences people's attitudes and lived realities in the neighbourhood context [72]. The residents' perceptions [44,45] about the front yard's usability can influence the activity patterns of socialising which are able to contribute for enhanced sense of community. Table 2 presents the demographic profile of the interviewees. It shows that the majority are homeowners (66\%), female (59\%), of working age ( $87 \%$ with $48 \%$ being people between 45 and 64 ) and working $(85 \%$ with $41 \%$ on a full-time basis, $23 \%$ on a part-time basis and $21 \%$ self-employed or freelance) as professionals, including managers (54\%).

Table 2. Demographic profile of the interviewees in Subiaco case neighbourhood.

\begin{tabular}{lcc}
\hline Characteristic & Number & Percentage (\%) \\
\hline Home ownerships & 40 & 66 \\
Homeowner & 17 & 28 \\
Tenant & 4 & 6 \\
Other & & \\
\hline Gender & 36 & 59 \\
Female & 25 & 41 \\
Male & & \\
\hline Age & 3 & 5 \\
18-23 & 8 & 13 \\
24-35 & 13 & 21 \\
36-44 & 29 & 48 \\
45-64 & 8 & 13 \\
>64 & & \\
\hline Employment & 25 & 41 \\
Full-time & 14 & 23 \\
Part-time & 13 & 21 \\
Self-employed/freelance & 5 & 8 \\
Studying & 4 & 7 \\
Unemployed & & 100 \\
\hline Profession & 10 & 38 \\
Managers & 23 & 20 \\
Professional & 12 & \\
Other professions & 16 & \\
Without an identified profession & 61 & \\
\hline TOTAL & & \\
\hline
\end{tabular}

Both, observation and perception analyses generated insights about the selected case neighbourhood. The findings, including the developed typology of closeness, are described below.

\subsection{Case Study}

The case study for this analysis is a neighbourhood in Subiaco—a suburb situated at the immediate west of the central business district of Western Australia's capital city of Perth. Geographically, it is 
five kilometres east of the Indian Ocean, $12 \mathrm{~km}$ northeast of the port of Fremantle, and is situated north of the Swan River (see Figure 3). According to the Australian Bureau of Statistics [73], the 2016 resident population of Subiaco was 16,234, with a density of 31 persons per hectare over a total land area of 562 hectares $\left(6 \mathrm{~km}^{2}\right)$.

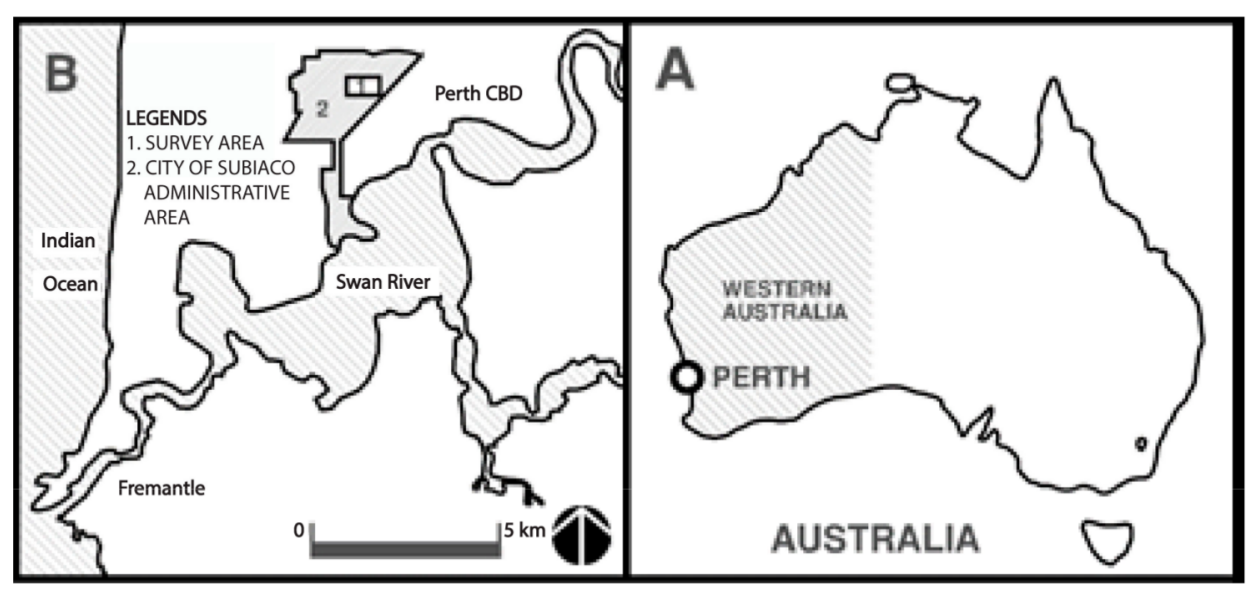

Figure 3. Maps of: Australia (A); and Subiaco (B) (Source: Authors).

Established in the 1880s as part of the development of the Swan Colony [74] and following its working-class origins in the early 20th century [75], Subiaco emerged as a culturally vibrant centre in the 1990s encouraged by the proximity to the University of Western Australia. It is a relatively wealthy and well-educated suburb. The personal median annual income was A\$59,592 in 2016 compared to A $\$ 37,648$ in Western Australia and AUS\$34,424 in Australia, and half of the people above 15 have university education compared to 20\% for Western Australia and 22\% for Australia [76].

\subsection{Case Study Neighbourhood}

The selected neighbourhood area includes several streets in Subiaco, namely Axon Street, Townshend Road, Olive Street, Bedford Avenue, Barker Road, Park Street and Bagot Road (see Figures 4 and 5). It is an entirely residential area with no commercial or industrial enterprises. Each street has house front yards in a face to face and side by side manner allowing for social interaction between neighbours within their immediate vicinity.

The selected neighbourhood for the case study is a traditional inner-city part of Subiaco. It is representative of the original area which has stood up and adapted to the challenges of time. In Figure 4, it is marked as "survey area". Figure 4 also shows the main outdoor spaces and socialising places in Subiaco which include several parks and playgrounds, community centres, coffee shops, sports and recreation venues. The residents of the case neighbourhood have access to all of these places. This particular neighbourhood is relatively well-defined, unobstructed or divided by public open spaces making it distinctively local and relatively easy to explore the built form typology of social bonding for Subiaco residents.

Using a semi-structured questionnaire, the 61 interviews were conducted with residents in the selected neighbourhood about their front yards. The questionnaire canvassed demographic information (age, profession, home ownership, etc.; refer also to Table 2), opinions (on a Likert scale) and contained open-ended questions (comments, suggestions, recommendations, etc.). 


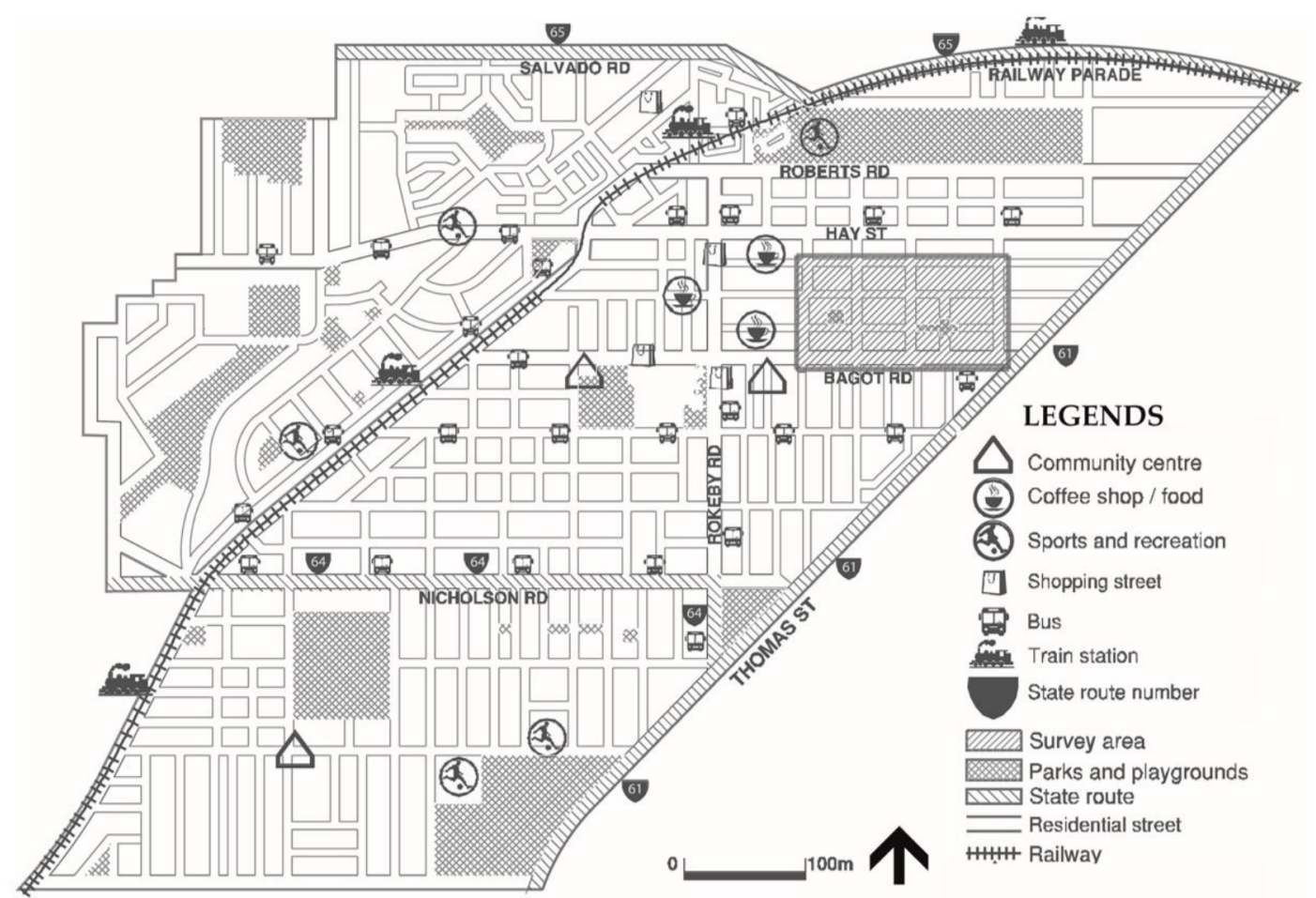

Figure 4. The suburb of Subiaco in Perth, Western Australia with the case neighbourhood (survey area) and public and outdoor places (Source: Authors).

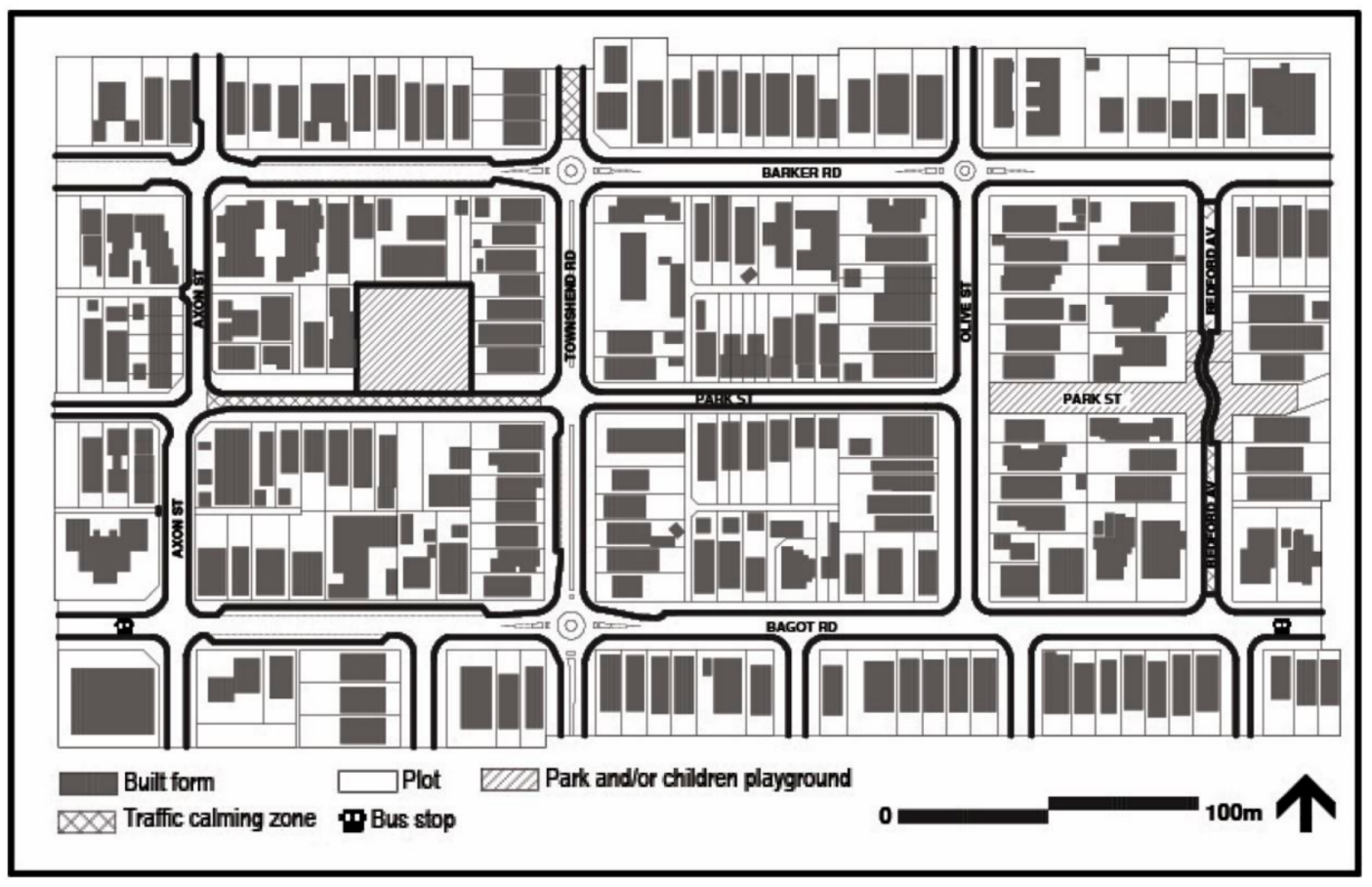

Figure 5. The case neighbourhood in Subiaco (Source: Authors).

\subsection{Typology of Communication}

Human interaction depends on the physical distance between people. It is based on immediate receptors such as skin, membrane and muscles, and distance receptors, such as eyes, ears and nose [51]. The former are used in close proximity while the latter enable people to see, hear and smell at a different 
degree depending on the distance (see Table 3). With eye sight allowing people the longest distance communication, Gehl [41] described the range up to $100 \mathrm{~m}$ (325 feet) as the social field of vision. In this range, human beings might engage in various degrees of communication and social interaction with each other. The assumption is that human contact is not capable of passive communication beyond $100 \mathrm{~m}$ based on anatomical receptors (seeing/hearing/smelling). On a neighbourhood street scale, however, $25 \mathrm{~m}$ (or 80 feet) is the threshold for perceiving and understanding the feelings and moods of others and hence the limit of meaningful social interactions.

Table 3. Human perception and level of contact intensity (based on [41]).

\begin{tabular}{|c|c|c|c|}
\hline & Receptor & Range & Purpose/Ability to Perform \\
\hline \multirow{2}{*}{$\begin{array}{c}\text { Short distance } \\
\uparrow \\
\text { Longer distance }\end{array}$} & \multirow{2}{*}{ Nose/Smell } & $1 \mathrm{~m}$ (39 inch) & Weak odour can be felt \\
\hline & & 2 to $3 \mathrm{~m}$ ( 7 to 10 feet) & $\begin{array}{l}\text { Strong smell like perfume } \\
\text { can be felt }\end{array}$ \\
\hline \multirow{2}{*}{$\begin{array}{c}\text { Shorter distance } \\
\uparrow \\
\text { Long distance }\end{array}$} & \multirow[b]{2}{*}{ Ear/Hearing } & $7 \mathrm{~m}$ (23 feet) (Maximum) & Normal conversation \\
\hline & & 35 m (100 feet) (Maximum) & $\begin{array}{l}\text { Lecture/question-answer session/one } \\
\text { way communication }\end{array}$ \\
\hline \multirow{6}{*}{$\begin{array}{c}\text { Short distance } \\
\uparrow \\
\text { Long distance }\end{array}$} & \multirow{6}{*}{ Eye/Sight } & 0 to $0.5 \mathrm{~m}$ ( 0 to 2 feet $)$ & Intense emotional contact \\
\hline & & 0.5 to $7 \mathrm{~m}$ ( 2 to 20 feet) & Less intense contacts \\
\hline & & 1 to $3 \mathrm{~m}$ ( 3 to 10 feet) & $\begin{array}{l}\text { Normal conversation, meaningful } \\
\text { human contact }\end{array}$ \\
\hline & & 20 to $25 \mathrm{~m}$ (60 to 80 feet) & Understanding of feeling or mood \\
\hline & & 30 m (100 feet) & $\begin{array}{l}\text { Recognition of age/facial } \\
\text { feature/hairstyle }\end{array}$ \\
\hline & & $\begin{array}{l}70 \text { to } 100 \mathrm{~m} \\
\text { (250 to } 325 \text { feet) }\end{array}$ & $\begin{array}{l}\text { Recognition of age/sex/activity } \\
\text { (e.g., people at the beach, football match) }\end{array}$ \\
\hline
\end{tabular}

Table 4 presents a communication typology based on social distance. The range of each category is determined based on a circle (see Figure $6 a, b$ ) that excludes any previous types. For example, social distance (category $\mathrm{C} 3$ ) excludes intimate (category $\mathrm{C} 1$ ) and personal (category $\mathrm{C} 2$ ) distances. Intimate (C1) and personal distances (C2) are limited to family and friends and useful for interactions in semi-private spaces (e.g., veranda).

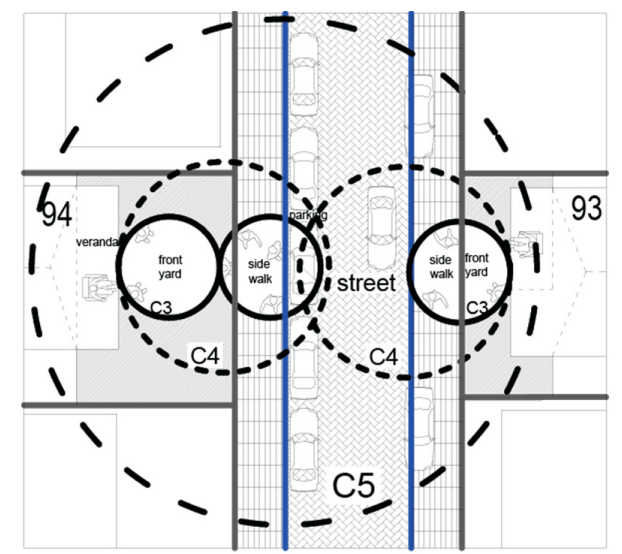

(a)

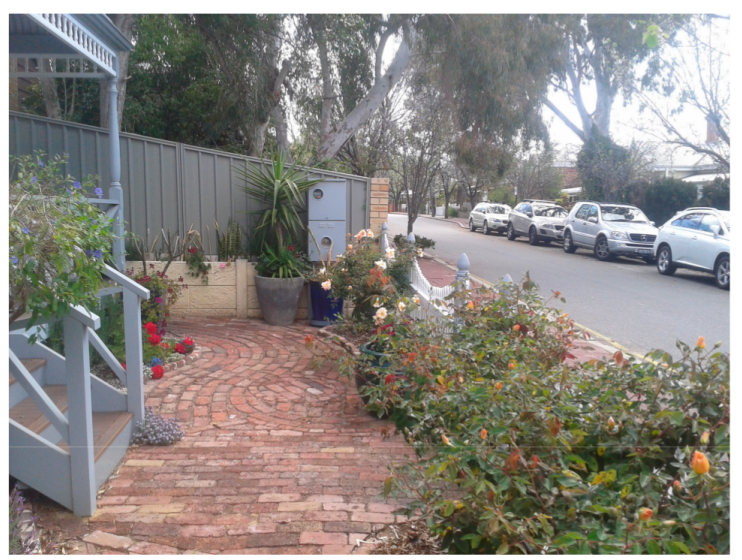

(b)

Figure 6. Section of Park Street in Subiaco, Perth, Western Australia: (a) top view of the inter-relationships between the front yards on both sides of Park Street showing the different distances, namely C3 (social distance), C4 (public distance) and C5 (recognisable distance); and (b) perspective view of Park Street showing different space types, including front-yard, sidewalk, street parking and street (Source: Authors). 
Table 4. Communication typology based on social distances [51].

\begin{tabular}{|c|c|c|c|c|}
\hline Sense & Level of Interaction & $\begin{array}{l}\text { Distance } \\
\text { Type }\end{array}$ & $\begin{array}{l}\text { Diameter } \\
\text { Range }\end{array}$ & Code \\
\hline Smell + Hearing + Sight & $\begin{array}{l}\text { High intensity contact (tenderness, comfort, } \\
\text { love, anger) }\end{array}$ & $\begin{array}{l}\text { Intimate } \\
\text { distance }\end{array}$ & $\begin{array}{l}0.45 \mathrm{~m} \\
(1.5 \text { feet })\end{array}$ & $\mathrm{C} 1$ \\
\hline Smell + Hearing + Sight & $\begin{array}{l}\text { Normal conversation (close friends, family, } \\
\text { e.g., family dinner table) }\end{array}$ & $\begin{array}{l}\text { Personal } \\
\text { distance }\end{array}$ & $\begin{array}{c}1.3 \mathrm{~m} \\
(4.5 \text { feet })\end{array}$ & $\mathrm{C} 2$ \\
\hline Hearing + Sight & $\begin{array}{l}\text { Ordinary conversations (friends, acquaintances, } \\
\text { neighbours, co-workers, etc.) }\end{array}$ & $\begin{array}{c}\text { Social } \\
\text { distance }\end{array}$ & $\begin{array}{l}3.75 \mathrm{~m} \\
(12 \mathrm{feet})\end{array}$ & $\mathrm{C} 3$ \\
\hline Hearing + Sight & $\begin{array}{l}\text { Formal contacts usually when someone } \\
\text { watches, hears but may not want to participate } \\
\text { (teaching, one-way communication) }\end{array}$ & $\begin{array}{l}\text { Public } \\
\text { distance }\end{array}$ & $\begin{array}{c}7 \mathrm{~m} \\
(25 \mathrm{feet})\end{array}$ & $\mathrm{C} 4$ \\
\hline Hearing + Sight & $\begin{array}{l}\text { Normal voices are lost, facial expressions and } \\
\text { movements are difficult to recognise; the main } \\
\text { recognisable features are gestures and postures. }\end{array}$ & $\begin{array}{l}\text { Recognisable } \\
\text { distance }\end{array}$ & $\begin{array}{c}20 \mathrm{~m} \\
(60 \mathrm{feet})\end{array}$ & C5 \\
\hline Hearing + Sight & $\begin{array}{l}\text { People are able to perceive feelings and moods } \\
\text { while meeting others; this is the threshold of } \\
\text { meaningful social interactions. }\end{array}$ & $\begin{array}{l}\text { Identifiable } \\
\text { distance }\end{array}$ & $\begin{array}{c}25 \mathrm{~m} \\
(80 \mathrm{feet})\end{array}$ & C6 \\
\hline Hearing + Sight & $\begin{array}{l}\text { One-way communication (e.g., lecture with } \\
\text { questions and answers or a theatre } \\
\text { performance), visibility and participation in a } \\
\text { conversation are difficult; only infrequent } \\
\text { contacts are possible }\end{array}$ & $\begin{array}{l}\text { Observing } \\
\text { distance }\end{array}$ & $\begin{array}{c}35 \mathrm{~m} \\
(100 \mathrm{feet})\end{array}$ & $\mathrm{C} 7$ \\
\hline Sight & $\begin{array}{l}\text { People can recognise others' gender, } \\
\text { approximate age and type of activity. }\end{array}$ & $\begin{array}{l}\text { Visible } \\
\text { distance }\end{array}$ & $\begin{array}{c}100 \mathrm{~m} \\
\text { (325 feet) }\end{array}$ & $\mathrm{C} 8$ \\
\hline
\end{tabular}

In a neighbourhood scale, the interactions within the semi-private-public (front yard) and public (e.g., sidewalk, verge, street parking, street, etc.) spaces are crucial for this study and they fall within the C3 (social distance) and C4 (public distance) categories. Social distances (C3) allow comfortable interactions between friends, neighbours and co-workers. Public distance (C4) is just double the size of social distance (C3). If a front yard and sidewalk fall within the range of social distance (C3), then the physical condition is considered as highly communicative for encouraging community interactions. When a front yard and sidewalk are within public distance (C4), this is seen as a medium communicative physical condition. Any distance beyond $\mathrm{C} 4$ is considered as low communicative physical conditions and typically falls within the distance range of C5 (recognisable distance). Recognisable distance (C5) helps to determine the level of social interaction between front yards across the street. In this range, people cannot talk comfortably as their voices are lost or fade. It is also difficult to clearly understand the facial expressions or movements of the other persons across the street. However, people can still identify the gestures and postures of others from this distance. Hence, a passive communication prevails. This situation is good for natural surveillance [29] but not for normal conversation. Natural surveillance is encouraged in planning schemes in various parts of the world with the aim to reduce crime. This is one of the main principles of Crime Prevention Through Environmental Design (CPTED) [77].

Categories C3-C5 are the ones of interest for analysing community building at a neighbourhood level. They can also represent the level of social closeness within the community based on the physical distance (see Table 5). The interaction and communication level is determined by the distance between the edge of the veranda and the centre point of the sidewalk. 
Table 5. Scale of closeness based on distance categories.

\begin{tabular}{cccc}
\hline Category & Physical Distance & Distance Category & Scale of Social Closeness \\
\hline C3 & $\begin{array}{c}\text { From } 1.3 \text { to } 3.75 \mathrm{~m} \\
(4.5 \text { to } 12 \text { feet })\end{array}$ & Social distance & High closeness \\
\hline C4 & $\begin{array}{c}\text { From } 3.75 \text { to } 7 \mathrm{~m} \\
\text { (12 to } 25 \text { feet })\end{array}$ & Public distance & Medium closeness \\
\hline C5 & $\begin{array}{c}\text { From } 7 \text { to } 20 \mathrm{~m} \\
\text { (25 to } 60 \text { feet })\end{array}$ & Recognisable distance & Low closeness \\
\hline
\end{tabular}

\section{Discussion of Case Study Results}

Four of the seven streets in the case study neighbourhood have a north-south orientation, namely Axon Street, Townshend Road, Olive Street and Bedford Avenue, while the remaining three-Barker Road, Park Street and Bagot Road-are oriented along east-west (see Figure 7 for snapshots of the case neighbourhood). The house numbers considered for inclusion in the study for each street are based on the orientation of the front yard rather than the address. For instance, the orientation of the front yard of a corner plot, rather than the postal address, defines whether a house falls under a particular street. Moreover, the front yard's orientation is important to observe the face-to-face (houses opposite to each other) or side-by-side (houses adjacent to each other) interaction level between immediate neighbours. The results from the detailed observation and the perception-based survey are presented below.

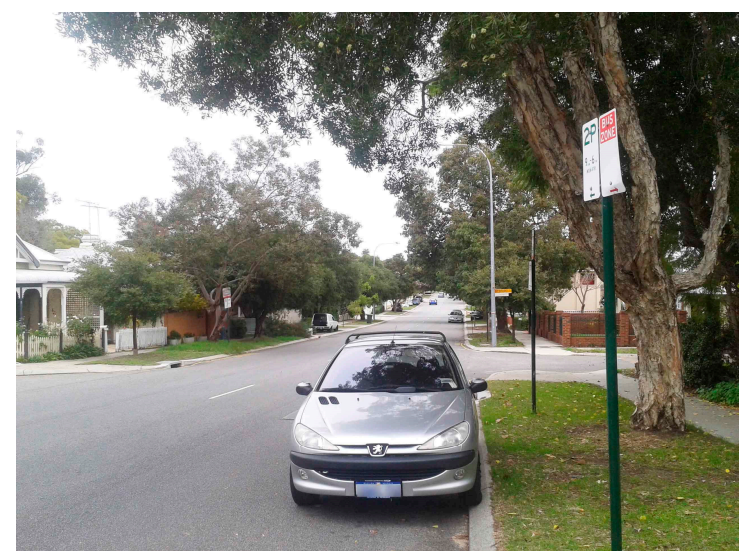

(a)

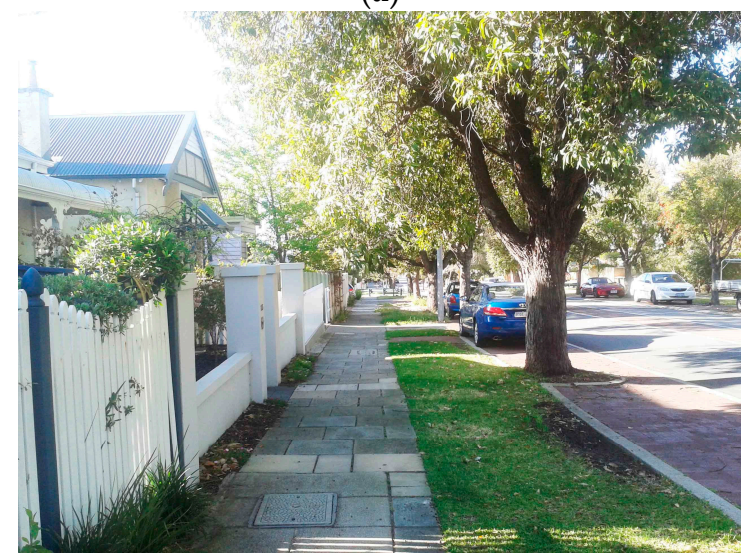

(c)

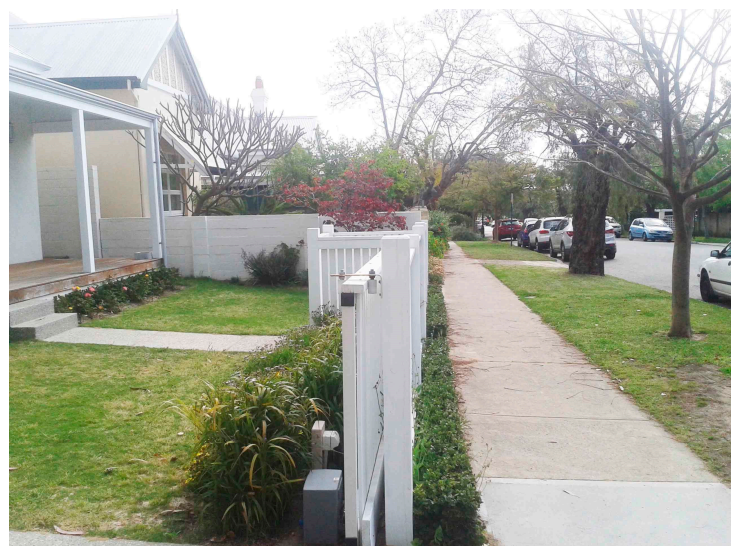

(b)

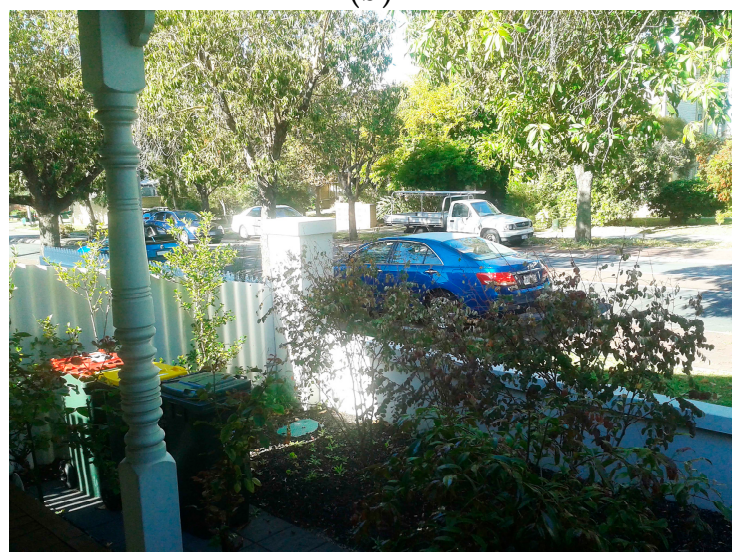

(d)

Figure 7. Cont. 


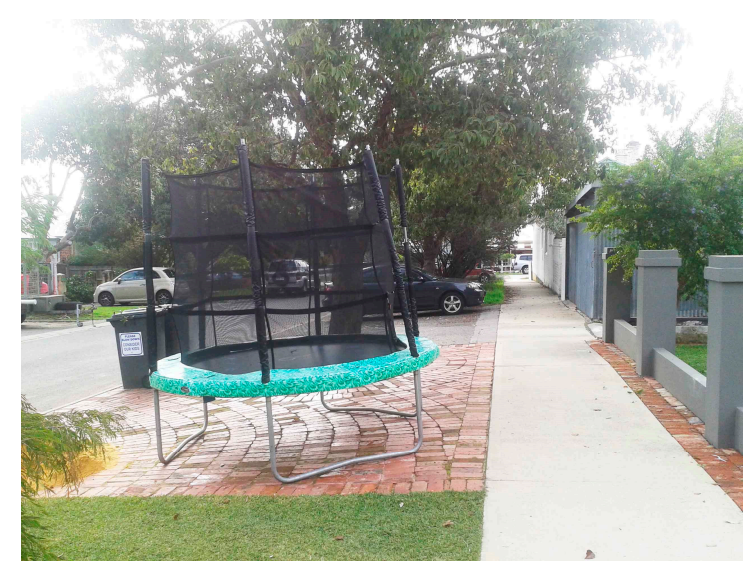

(e)

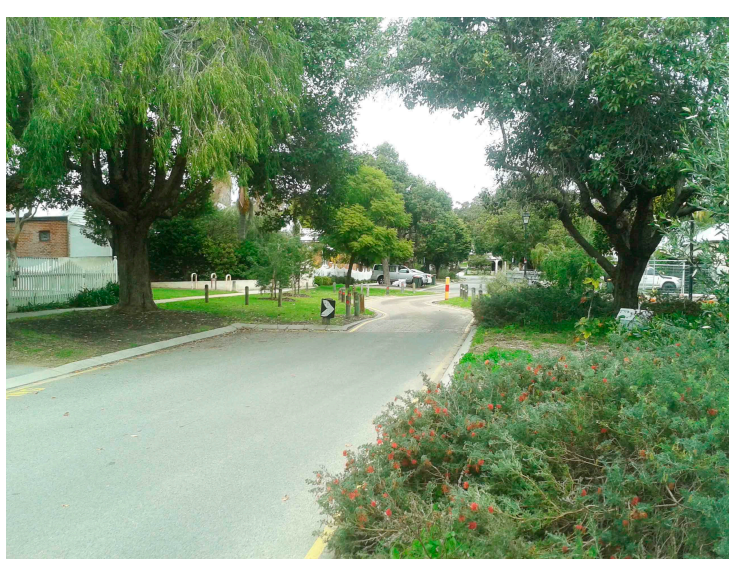

(f)

Figure 7. Snapshots of Subiaco case neighbourhood: (a) Bagot Road view shows wider streets with bus routes; (b) Barker Road view shows a wide sidewalk along a fenced front yard; (c) Townshend Road view shows a sidewalk along different types of fenced front yards; (d) Townshend Road view from a veranda overlooking sidewalks, verge, parking and neighbouring front yards across the street; (e) Bedford Avenue view shows the use of the verge as an extended playground; and (c) traffic calming in Bedford Avenue (Source: Authors).

\subsection{Detailed Observation}

Table 6 shows the closeness patterns in the Subiaco case study neighbourhood. The majority of houses in the entire neighbourhood, and in all streets with the exception of Bedford Avenue, belong to the medium social closeness category (C4). At the two extremes are Olive Street, where all houses fall within this public distance category, and Bedford Avenue, where they are evenly spread between medium (C4) and low (C5) closeness. Hence, the front yards of Bedford Avenue have the lowest level of closeness compared to the other streets. The reason is the wider front yards which prevent residents and users to communicate with pedestrians. Although Bedford Avenue is a street controlled with traffic calming, it has the least pedestrian movement observed. The front yards in Olive Street have a uniform width. The observation showed this to be the least interactive street due to its quiet ambience. Being a cul-de-sac might hinder the level of social interaction.

Table 6. Social closeness patterns in the Subiaco case neighbourhood.

\begin{tabular}{cccc}
\hline & \multicolumn{3}{c}{ Closeness } \\
\cline { 2 - 4 } Street Name & High & Medium & Low \\
\cline { 2 - 4 } & $\mathbf{C 3}$ & $\mathbf{C 4}$ & $\mathbf{C 5}$ \\
\cline { 2 - 4 } & $\mathbf{\%}$ & $\mathbf{\%}$ & $\mathbf{\%}$ \\
\hline Axon Street & 22 & $\mathbf{7 8}$ & 0 \\
Townshend Road & 17 & $\mathbf{1 0 0}$ & 0 \\
Olive Street & 0 & $\mathbf{5 0}$ & $\mathbf{5 0}$ \\
Bedford Avenue & 0 & $\mathbf{7 9}$ & 4 \\
Barker Road & 17 & $\mathbf{5 2}$ & 9 \\
Park Street & $\mathbf{3 9}$ & $\mathbf{6 7}$ & 16 \\
Bagot Road & 17 & $\mathbf{7 2}$ & 10 \\
All streets & 18 & &
\end{tabular}

The front yards of the remaining five streets exhibit a combination between high and medium social closeness with social and public distances. Park Street has the highest share of high social closeness (C3) with 39\% of its front yards belonging to this category. 
It is important to stress that the front yard width and driveway width are crucial factors in this analysis. If the front yard is around $3.75 \mathrm{~m}$ (12 feet) wide, that is across the street or less, the possibility for social interaction is high. In such a situation, it is easy for relationships between the front yard, sidewalk, verge or parking to take place. On the other hand, the relationship between the house front yards across the street depends greatly on the width of the driveways. In the case of Park Street, both the front yards and driveways are narrow enough to facilitate high level of social interactions. Furthermore, traffic calming, low speed and comfortable shaded and paved amenities are all factors which make the physical environment suitable for fostering social interactions.

The above analysis shows that all streets in the surveyed area are able to accommodate medium level of social interactions. Park Street can be identified as the one with the highest social closeness while Bedford Avenue has the lowest.

Front yards with high levels of closeness (C3) can accommodate very effective social encounters between neighbours in close proximity. As medium closeness (C4) distances are just double the distance (diameter) of $\mathrm{C} 3$, people can communicate with each other in a moderately comfortable way. Based on physical distance, only a small share of the front yards in this Subiaco neighbourhood (namely $10 \%$ ) have low social closeness.

Previous studies $[43,62,63]$ have shown that physical distance is important in determining social contacts. The relationship between physical distance and social interaction between individuals is essential to better understand ordinary social life [47,54,55]. Our regular activities-going to work, children going to school, cleaning, moving rubbish bins, walking dogs, collecting the mail, strolling and so on-are predictable, which is a tremendous opportunity to design the urban social settings by manipulating the existing physical spaces and routes [47]. Bay's [58] study further extended this concept within a high-rise residential apartment context and similar patterns are observable in all neighbourhoods. A social reformation of the regular residential physical environment is predictable which is impossible in the public space because of its anonymous character. Familiar faces enable acquaintances and brings people closer. Regular and repeated interactions make people closer and create the sense of community.

\subsection{Perception Survey}

Table 7 presents the survey results from the 61 interviews conducted in the neighbourhood area. The first three questions indicate the degree of social interaction in terms of physical distance. Saying hello is a weak one-way communication which takes place when two persons communicate with each other from a distance where watching is comfortable but hearing is not (see Tables 2 and 3 ). It corresponds to public distance (C4) or medium closeness. On the other hand, "talking" or "chatting" is only possible where two-way communication takes place and corresponds to social distance (C3) or high closeness. Inviting neighbours, passers-by or visitors may be possible only with the house owner's permission at a personal distance (C2). These first three questions show that there is a strong and direct relationship between the linear physical distance and level of social closeness with residents from all streets, except Bagot Road, indicating that they are more likely to maintain a public distance than engage in closer interactions. Barker Road residents do not perceive any major differences between public and social distance with all happy to use both in relation to their front yards. Olive Street residents are similarly uniform in using the public distance while more Bagot Street residents prefer social to public distance. 
Table 7. Social interaction in the Subiaco case neighbourhood.

\begin{tabular}{|c|c|c|c|c|c|c|c|}
\hline \multirow{2}{*}{ Question } & $\begin{array}{l}\text { Axon } \\
\text { Street }\end{array}$ & $\begin{array}{l}\text { Townshend } \\
\text { Road }\end{array}$ & $\begin{array}{l}\text { Olive } \\
\text { Street }\end{array}$ & $\begin{array}{l}\text { Bedford } \\
\text { Avenue }\end{array}$ & $\begin{array}{l}\text { Barker } \\
\text { Road }\end{array}$ & $\begin{array}{l}\text { Park } \\
\text { Street }\end{array}$ & $\begin{array}{l}\text { Bagot } \\
\text { Road }\end{array}$ \\
\hline & $\%$ Yes & $\%$ Yes & $\%$ Yes & $\%$ Yes & $\%$ Yes & $\%$ Yes & $\%$ Yes \\
\hline $\begin{array}{l}\text { 1. I like to say hello to my } \\
\text { neighbours from my front } \\
\text { yard (C4). }\end{array}$ & 92 & 90 & 100 & 70 & 100 & 86 & 70 \\
\hline $\begin{array}{l}\text { 2. I like to talk to my } \\
\text { neighbours in my front } \\
\text { yard (C3). }\end{array}$ & 87 & 80 & 86 & 59 & 100 & 86 & 80 \\
\hline $\begin{array}{l}\text { 3. I like to invite my } \\
\text { neighbours in my front yard } \\
\text { to participate in daily life or } \\
\text { recreational activities (C2). }\end{array}$ & 49 & 40 & 43 & 59 & 85 & 36 & 70 \\
\hline $\begin{array}{l}\text { 4. I feel the front yard is an } \\
\text { appropriate place to } \\
\text { participate in community life. }\end{array}$ & 72 & 70 & 100 & 45 & 82 & 57 & 90 \\
\hline $\begin{array}{l}\text { 5. I made new friends in my } \\
\text { front yard during the last } \\
\text { few years. }\end{array}$ & 64 & 80 & 71 & 96 & 43 & 50 & 90 \\
\hline $\begin{array}{l}\text { 6. I feel a strong sense of } \\
\text { ownership and sense of } \\
\text { belonging in the front yard of } \\
\text { my house which help me to } \\
\text { engage with my } \\
\text { neighbourhood community. }\end{array}$ & 77 & 80 & 100 & 62 & 87 & 50 & 100 \\
\hline $\begin{array}{l}\text { 7. I think my front yard } \\
\text { allows building familiarity } \\
\text { with my neighbours and } \\
\text { encourages involvement in } \\
\text { community activities. }\end{array}$ & 64 & 70 & 72 & 45 & 75 & 72 & 40 \\
\hline Average level of closeness & 72 & 73 & 82 & 62 & 82 & 62 & 77 \\
\hline
\end{tabular}

It is interesting to see that the perceptions about the role of the front yards in creating sense of community can either mirror the physical distances or compensate for them. For example, all front yards on Olive Street have medium social closeness (see Table 6) and again all residents feel that the front yard is an appropriate place to socialise. On the contrary, Bedford Avenue is the street with the longest physical distance and while the front yard is perceived as a place to socialise only by $45 \%$ of the residents, $96 \%$ admit of having made new friends there in recent years. Park Street has the shortest distances but only $36 \%$ of its residents perceive the front yards as a socialising place. Overall, most residents feel a strong sense of ownership and belonging in the front yard of the house which helps them engage with their neighbourhood community. On Olive and Bagot Streets this perception is shared by all residents, while on Park Street only by half of them. The perceptions about the role of the front yards in developing closer relationships at the level of familiarity are shared by a smaller number of residents, as low as $40 \%$ for Bagot Road and $45 \%$ for Bedford Avenue. Hence, there are big differences in perceptions about the role of the front yards in creating a sense of community which not always align with the theoretical framework about the role of distance in creating social relationships.

\subsection{Typology of Closeness}

The typology of closeness based on the physical distance is perceived differently by the residents of the Subiaco case neighbourhood. In all residential streets, the number of front yards with medium level of social closeness is the highest. However, for three of them the perceived closeness was lower than the one determined based on the physical distance while for the remaining four, it was the 
opposite (see Table 8). This discrepancy requires further understanding of the social factors influencing people's perceptions. Notwithstanding this, the difference between the medium level of societal closeness and the average perceived level was relatively low (maximum 18\%). This shows that the physical distance can be used as a rough measure for social closeness.

Table 8. Medium level and average perceived social closeness in the Subiaco case neighbourhood.

\begin{tabular}{cccc}
\hline & \multicolumn{3}{c}{ Social Closeness } \\
\cline { 2 - 4 } Street Name & Medium & Perceived & Discrepancy \\
\cline { 2 - 4 } & Level & Level & \% \\
\cline { 2 - 4 } & \% & \% & 8 \\
Axon Street & 78 & 72 & 8 \\
Townshend Road & 79 & 73 & 18 \\
Olive Street & 100 & 82 & 4 \\
Bedford Avenue & 50 & 62 & 16 \\
Barker Road & 79 & 62 & 13 \\
Park Street & 52 & 77 & \\
Bagot Road & 67 & & \\
\hline
\end{tabular}

The three types of front yards based on physical distance allow for high (or social distance), medium (or public distance) and low (or recognisable distance) social closeness. They stimulate different types of interactions and social activities contributing to the sense of community. A distinctive feature of this typology is that it includes the link between the physical and social components which is rarely the case. Previous typology studies have ignored the role of the front yard as well as social aspects, and used only physical characteristics, such as scale and size (e.g., housing typology [78]), landscape features (e.g., parks [79]), traffic management (e.g., streets [80]), and architectural forms (e.g., buildings [81]) or used only social interactions (e.g., back alleys [82]). The study by Martin [82] mentions the front yard as a formal and uniform representation of the human personality with a desire to be seen from the public streets. This current study acknowledges the importance of both physical and social aspects in creating sense of community.

Understanding the typology of closeness also aligns with academic efforts to encourage safety and walkability in urban environments (e.g., [83]). It further emphasises the special role the front yards play as semi-private-public and socially interactive spaces.

\section{Conclusions}

The principles of sustainable development include resident-driven local communities [84] and the front yards in residential neighbourhood seem a logical place for initiating and maintaining social interactions. The distance-based observation study in the Subiaco neighbourhood confirmed the theory that social closeness is directly related to physical distance. There are however mixed results based on the residents' perceptions about the potential of the front yard. While overall the majority of residents on all seven streets gave some importance to the front yard in community building (ranging from $62 \%$ on Bedford and Park Streets to $82 \%$ on Olive Street and Barker Road), its place was perceived very differently. In some cases, it mirrored the physical distance, in others it was compensating for a longer or shorter distance by respectively being more or less used for socialising.

This study shows that theoretical understanding is not enough in design decision making during the planning process and testing of theory in application is required for proper diagnosis. Subiaco residents' behaviour in their semi-private-public front yards is a complex phenomenon that requires careful observation because the key to the design decisions lies beneath a blurred zone. Like every other case of human settlement around the world, Subiaco people have their own attitudes, practices, customs and beliefs which need proper understanding. Front yards in the selected Subiaco 
neighbourhood play an important role in this cultural background and the understanding uncovered in this study enriches our knowledge.

Subiaco residents' conservative response to their neighbours in close proximity proves their careful nature of being selective in choosing friends. The overall medium closeness level represents their moderately open-minded attitude during social interactions. They are not only careful about closer interactions, but also maintain the necessary basic relationships with their neighbours. This careful interpretation of a balanced nature is a unique quality to be considered in the planning process. Hence, the typology of closeness is an important tool to boost better understanding by different interest groups, including planners, urban designers, architects, policy makers and users, and help the sustainability agenda towards better communities.

Author Contributions: The three authors conceived and designed the study. A.Y.S. performed the data collection and analysed the results. All three authors wrote the paper.

Funding: Funding for research and publication was provided by Curtin University.

Conflicts of Interest: The authors declare no conflicts of interest.

\section{References}

1. Boyer, R.H.; Peterson, N.D.; Arora, P.; Caldwell, K. Five approaches to social sustainability and an integrated way forward. Sustainability 2016, 8, 878. [CrossRef]

2. Littig, B.; Griessler, E. Social sustainability: A catchword between political pragmatism and social theory. Int. J. Sustain. Dev. 2005, 8, 65-79. [CrossRef]

3. United Nations. World Urbanization Prospects: The 2014 Revision, Highlights; Department of Economic and Social Affairs, Population Division, United Nations: New York, NY, USA, 2014.

4. Sen, A. The ends and means of sustainability. J. Hum. Dev. Capab. 2013, 14, 6-20. [CrossRef]

5. Anand, S.; Sen, A. Sustainable Human Development: Concepts and Priorities; United Nations Development Programme, Office of Development Studies: New York, NY, USA, 1996.

6. Francis, M. Urban Open Space: Designing for User Needs; Island Press: Washington, DC, USA, 2003.

7. Francis, M. The making of democratic streets. Contesti Città Territori Progetti 2016, 192-213. [CrossRef]

8. Swapan, A.Y.; Marinova, D.; Bay, J.H. Understanding the importance of front yard accessibility for community building: A case study of Subiaco, Western Australia. Urban Sci. 2018, 2, 41. [CrossRef]

9. Lewin, S.S. Urban sustainability and urban form metrics. J. Green Build. 2012, 7, 44-63. [CrossRef]

10. Penn, A. Architectural research. In Advanced Research Methods in the Built Environment; Knight, A., Ruddock, L., Eds.; Wiley-Blackwell: Oxford, UK, 2008; pp. 14-27.

11. Williams, K.; Burton, E.; Jenks, M. Achieving sustainable urban form: An introduction. In Achieving Sustainable Urban Form; Williams, K., Burton, E., Jenks, M., Eds.; E \& FN Spon: London, UK, 2000; pp. 1-5.

12. Newman, P.; Jennings, I. Cities as Sustainable Ecosystems: Principles and Practices; Island Press: Washington, DC, USA, 2012.

13. Pretty, G.H.; Chipuer, H.M.; Bramston, P. Sense of place amongst adolescents and adults in two rural Australian towns: The discriminating features of place attachment, sense of community and place dependence in relation to place identity. J. Environ. Psychol. 2003, 23, 273-287. [CrossRef]

14. Davison, G.; Rowden, E. “There's something about Subi”: Defending and Creating Neighbourhood Character in Perth, Australia. J. Urban Des. 2012, 17, 189-212. [CrossRef]

15. McMillan, D.W.; Chavis, D.M. Sense of community: A definition and theory. J. Community Psychol. 1986, 14, 6-23. [CrossRef]

16. Prezza, M.; Amici, M.; Roberti, T.; Tedeschi, G. Sense of community referred to the whole town: Its relations with neighboring, loneliness, life satisfaction, and area of residence. J. Community Psychol. 2001, $29,29-52$. [CrossRef]

17. Granovetter, M. The strength of weak ties: A network theory revisited. Sociol. Theory 1983, 201-233. [CrossRef]

18. Prezza, M.; Costantini, S. Sense of community and life satisfaction: Investigation in three different territorial contexts. J. Community Appl. Soc. Psychol. 1998, 8, 181-194. [CrossRef] 
19. Kashef, M. Urban livability across disciplinary and professional boundaries. Front. Archit. Res. 2016, 5, 239-253. [CrossRef]

20. Bramley, G.; Dempsey, N.; Power, S.; Brown, C. What is 'social sustainability', and how do our existing urban forms perform in nurturing it. In Sustainable Communities and Green Futures, Planning Research Conference, Bartlett School of Planning; University College London: London, UK, 2006.

21. Dempsey, N.; Bramley, G.; Power, S.; Brown, C. The social dimension of sustainable development: Defining urban social sustainability. Sustain. Dev. 2011, 19, 289-300. [CrossRef]

22. Dujon, V.; Dillard, J.; Brennan, E.M. Social Sustainability: A Multilevel Approach to Social Inclusion; Routledge: New York, NY, USA, 2013.

23. Jabareen, Y.R. Sustainable urban forms: Their typologies, models, and concepts. J. Plan. Educ. Res. 2006, 26, 38-52. [CrossRef]

24. Eizenberg, E.; Jabareen, Y. Social sustainability: A new conceptual framework. Sustainability 2017, 9, 68. [CrossRef]

25. McKenzie, S. Social Sustainability: Towards Some Definitions; Hawke Research Centre, University of South Australia: Adelaide, Australia, 2004.

26. Vallance, S.; Perkins, H.C.; Dixon, J.E. What is social sustainability? A clarification of concepts. Geoforum 2011, 42, 342-348. [CrossRef]

27. Barron, L.; Gauntlett, E. Housing and Sustainable Communities Indicators Project: Stage 1 Report Model of Social Sustainability; Western Australian Council of Social Services: Perth, Australia, 2002.

28. Woodcraft, S.; Hackett, T.; Caistor-Arendar, L. Design for Social Sustainability: A Framework for Creating Thriving New Communities; Young Foundation: London, UK, 2011.

29. Jacobs, J. The Death and Life of American Cities; Vintage Books: New York, NY, USA, 1993.

30. Fekadu, K. The paradox in environmental determinism and possibilism: A literature review. J. Geogr. Reg. Plan. 2014, 7, 132-139. [CrossRef]

31. Chiodi, S.I. Crime prevention through urban design and planning in the smart city era: The challenge of disseminating CP-UDP in Italy: Learning from Europe. J. Place Manag. Dev. 2016, 9, 137-152. [CrossRef]

32. Scott, A. Design strategies for green practice. J. Green Build. 2006, 1, 11-27. [CrossRef]

33. Caniggia, G.; Maffei, G.L. Architectural Composition and Building Typology: Interpreting Basic Building; Alinea Editrice: Florence, Italy, 2001.

34. Moudon, A.V. The role of typomorphological studies in environmental design research. In Changing Paradigms; Hardie, G., Moore, R., Sanoff, H., Eds.; University of Washington: Seattle, WA, USA, 1989; pp. 41-48.

35. Conzen, M.R. Thinking about Urban Form: Papers on Urban Morphology 1932-1998; Peter Lang: New York, NY, USA, 2004.

36. Moudon, A.V. Urban morphology as an emerging interdisciplinary field. Urban Morphol. 1997, 1, 3-10.

37. Madanipour, A. Public and Private Spaces of the City; Routledge: London, UK, 2003.

38. Simmel, G. The Sociology of Georg Simmel; Wolff, Kurt H., Translator; Andesite Press: New York, NY, USA, 2017.

39. Iveson, K. Strangers in the cosmopolis. In Cosmopolitan Urbanism; Binnie, J., Holloway, J., Millington, S., Young, C., Eds.; Routledge: London, UK, 2006; pp. 70-86.

40. Dovey, K.; Wood, S. Public/private urban interfaces: Type, adaptation, assemblage. J. Urban. 2015, 8, 1-16. [CrossRef]

41. Gehl, J. Life between Buildings; Van Nostrand Reinhold: New York, NY, USA, 1987.

42. Whyte, W.H. The Social Life of Small Urban Spaces; Conservation Foundation: Washington, DC, USA, 1980.

43. Hester, R.T. Planning Neighborhood Space with People; Van Nostrand Reinhold: New York, NY, USA, 1984.

44. Carmona, M. Contemporary public space: Critique and classification, part one: Critique. J. Urban Des. 2010, 15, 123-148. [CrossRef]

45. Carmona, M. Contemporary public space, part two: Classification. J. Urban Des. 2010, 15, 157-173. [CrossRef]

46. Barker, R.G. Ecological Psychology: Concepts and Methods for Studying the Environment of Human Behavior; Stanford University Press: Stanford, CA, USA, 1968.

47. Chua, B.H. A practicable concept of community in high-rise, high density housing environment. Singap. Archit. 1995, 189, 95.

48. Knight, J.A.; Vallacher, R.R. Interpersonal engagement in social perception: The consequences of getting into the action. J. Personal. Soc. Psychol. 1981, 40, 990-999. [CrossRef] 
49. Fournier, G. Mere Exposure Effect. Psych Central. 2016. Available online: https://psychcentral.com/ encyclopedia/mere-exposure-effect/ (accessed on 4 May 2018).

50. French, S.; Wood, L.; Foster, S.A.; Giles-Corti, B.; Frank, L.; Learnihan, V. Sense of community and its association with the neighborhood built environment. Environ. Behav. 2014, 46, 677-697. [CrossRef]

51. Hall, E.T. The Hidden Dimension; Peter Smith Pub.: Gloucester, MA, USA, 1992.

52. Gehl, J. "Soft edges" in residential streets. Scand. Hous. Plan. Res. 1986, 3, 89-102. [CrossRef]

53. Bonevento, M.D. It's a Small World after All: Mapping Social Space. Master's Thesis, Florida Atlantic University, Boca Raton, FL, USA, 1995.

54. Latané, B.; Liu, J.H.; Nowak, A.; Bonevento, M.; Zheng, L. Distance matters: Physical space and social impact. Personal. Soc. Psychol. Bull. 1995, 21, 795-805. [CrossRef]

55. Latané, B.; Wolf, S. The social impact of majorities and minorities. Psychol. Rev. 1981, 88, 438-453. [CrossRef]

56. Latané, B.; Liu, J.H. The intersubjective geometry of social space. J. Commun. 1996, 46, 26-34. [CrossRef]

57. Latané, B.; Nowak, A.; Liu, J.H. Measuring emergent social phenomena: Dynamism, polarization, and clustering as order parameters of social systems. Syst. Res. Behav. Sci. 1994, 39, 1-24. [CrossRef]

58. Bay, J.H. Towards a fourth ecology: Social and environmental sustainability with architecture and urban design. J. Green Build. 2010, 5, 176-197. [CrossRef]

59. Bay, J.H.P.; Lehmann, S. (Eds.) Growing Compact: Urban Form, Density and Sustainability; Taylor \& Francis: Oxford, UK, 2017.

60. Wang, N.; Bay, J.H. Parametric simulation and pre-parametric design thinking: Guidelines for socio-climatic design of high-rise semi-open spaces. In Understanding Meaningful Environments: Architectural Precedents and the Question of Identity in Creative Design, Proceedings of the 21st Conference on Passive and Low Energy Architecture; University of Technology: Eindhoven, The Netherlands, 2004.

61. Baym, N.K.; Zhang, Y.B.; Lin, M.-C. Social interactions across media: Interpersonal communication on the internet, telephone and face-to-face. New Media Soc. 2004, 6, 299-318. [CrossRef]

62. Kraut, R.; Patterson, M.; Lundmark, V.; Kiesler, S.; Mukophadhyay, T.; Scherlis, W. Internet paradox: A social technology that reduces social involvement and psychological well-being? Am. Psychol. 1998, 53, 1017-1031. [CrossRef] [PubMed]

63. Miller, D.; Slater, D. The Internet: An Ethnographic Approach; Berg Publisher: New York, NY, USA, 2003.

64. Haythornthwaite, C. Strong, weak, and latent ties and the impact of new media. Inf. Soc. 2002, 18, 385-401. [CrossRef]

65. Groat, L.N.; Wang, D. Architectural Research Methods, 2nd ed.; John Wiley \& Sons: Hoboken, NJ, USA, 2013.

66. Sahlqvist, S.; Goodman, A.; Jones, T.; Powell, J.; Song, Y.; Ogilvie, D. Mechanisms underpinning use of new walking and cycling infrastructure in different contexts: Mixed-method analysis. Int. J. Behav. Nutr. Phys. Act. 2015, 12, 24. [CrossRef] [PubMed]

67. Yin, R.K. Validity and generalization in future case study evaluations. Evaluation 2013, 19, 321-332. [CrossRef]

68. Mehta, V. Look closely and you will see, listen carefully and you will hear: Urban design and social interaction on streets. J. Urban Des. 2009, 14, 29-64. [CrossRef]

69. Gehl, J.; Svarre, B. How to Study Public Life; Island Press: Washington, DC, USA, 2013.

70. Harrell, M.C.; Bradley, M.A. Data Collection Methods. Semi-Structured Interviews and Focus Groups; Rand National Defense Research Institute: Santa Monica, CA, USA, 2009.

71. Morris, C. (Ed.) Academic Press Dictionary of Science and Technology; Academic Press: San Diego, CA, USA, 1992.

72. Valentin, V.; Bogus, S.M. Assessing the link between public opinion and social sustainability in building and infrastructure projects. J. Green Build. 2015, 10, 177-190. [CrossRef]

73. City of Subiaco. Community Profile. Available online: http://profile.id.com.au/subiaco/five-year-agegroups (accessed on 10 May 2018).

74. Howe, A.; Glass, G.; Curtis, C. Retrofitting TOD and managing the impacts: The case of Subi Centro. In Transit Oriented Development: Making It Happen; Curtis, C., Renne, J.L., Bertolini, L., Eds.; Ashgate: Farnham, UK, 2009; pp. 65-73.

75. Spillman, K. Tales of a Singular City: Subiaco since the 1970s; City of Subiaco: Perth, Australia, 2006.

76. Australian Bureau of Statistics. 2016 Census QuickStats. Available online: http:/ /www.censusdata.abs.gov. au/census_services/getproduct/census/2016/quickstat/SSC51405 (accessed on 10 May 2018). 
77. Crowe, T.D.; Fennelly, L.J. Crime Prevention through Environmental Design, 3rd ed.; Elsevier: Waltham, MA, USA, 2013.

78. Taghipour, M.; Soltanzadeh, H.; Afkan, K.B. The role of spatial organization in the typology of Shiraz (Iran) residential complexes. Adv. Environ. Sci. 2015, 7, 338-350.

79. Isling, B. A typology for the parks of Stockholm. Gard. Hist. 2004, 32, 248-260. [CrossRef]

80. Shrestha, B.K. Street typology in Kathmandu and street transformation. Urbani Izziv 2011, 22, $107-121$. [CrossRef]

81. Tice, J. Theme and variations: A typological approach to housing design, teaching, and research. J. Archit. Educ. 1993, 46, 162-175. [CrossRef]

82. Martin, M.D. The case for residential back-alleys: A North American perspective. J. Hous. Built Environ. 2002, 17, 145-171. [CrossRef]

83. Kim, J.; Kaplan, R. Physical and psychological factors in sense of community: New urbanist Kentlands \& nearby Orchard Village. Environ. Behav. 2004, 36, 313-340.

84. Holtzman, G. Community by design, by the people: Social approach to designing and planning cohousing and ecovillage communities. J. Green Build. 2014, 9, 60-82. [CrossRef]

(C) 2018 by the authors. Licensee MDPI, Basel, Switzerland. This article is an open access article distributed under the terms and conditions of the Creative Commons Attribution (CC BY) license (http:/ / creativecommons.org/licenses/by/4.0/). 